\title{
ANALYZING LAND USE PATTERN CHANGES IN MUKIM PENGERANG, JOHOR, MALAYSIA
}

\author{
N. Che'Man ${ }^{\mathrm{a}}$, A. F. Salihin ${ }^{\mathrm{a}}$ \\ ${ }^{a}$ Department of Urban and Regional Planning, Faculty of Built Environment and Surveying, University Teknolog Malaysia, Malaysia
}

\section{Article Info:}

Received: 19 July 2018

in revised form: 20 Sept 2018

Accepted: 1 Oct 2018

Available Online: 25 Oct 2018

\section{Keywords:}

Land Use Pattern Change, Fragstat, Urbanization

\section{Corresponding Author:}

Noordini binti Che Man

Department of Urban and Regional

Planning, Faculty of Built

Environment and Surveying,

Universiti Teknologi Malaysia

Email: b-noordini@utm.my

\begin{abstract}
Urbanization and urban land-use transition have a competitive environment to ensure and provide good facilities for citizen benefit. Thus, quantifying the spatiotemporal pattern of urbanization is important for understanding its ecological impacts and can provide basic information for appropriate decision-making. The growth of urbanization in Mukim Pengerang, Johor, has undergone rapid changes in agriculture, settlements, townships and various activities. The changes of the land uses are due to the rapid economic development, which are the Refinery and Petrochemical Integrated Development (RAPID) project and Pengerang Integrated Petroleum Complex (PIPC). The industrialization projects boost the growth in land property and commercial which progressing in rapid development since the year 2012. Therefore, the main aim of this paper is to quantify the changes in landscape pattern or land use pattern between the year 2008 and 2017 occurred in Mukim Pengerang. In monitoring the spatial pattern changes, and the changes of landscape structure, the metrics landscape were analyzed with determination of the Shanon Diversity Index (SHDI), the number of patches (NP), Edge Density (ED) and Total Edge (TE) in the period of 8 years. The results show that the changes occurred with the three types of land use showed significant changes in the types of land use which are forest, agricultural and built-up area. The result of SHDI analysis shows the increment value between the year 2008 and 2017. This situation illustrates that the higher value of SHDI for an area, resulting in the higher level of land use. This is because the growing pattern of land use is reflected by a large number of patches due to the diversification of land use activities in the area. As a result, from the metrics statistics test verifies there was a significant change in land use that took place within 8 years.
\end{abstract}

Copyright (C) 2018 GJGP-UNDIP This open access article is distributed under a Creative Commons Attribution (CC-BY-NC-SA) 4.0 International license.

How to cite (APA 6th Style): Che'Man, N., \& Salihin, A. F. (2018). Analyzing Land Use Pattern Changes in Mukim Pengerang, Johor, Malaysia. Geoplanning: Journal of Geomatics and Planning, 5(2), 229-236. doi: 10.14710/geoplanning.5.2.229-236.

\section{INTRODUCTION}

City development and shifts of urban use are a challenge to ensure citizens' welfare is adequately protected and available sufficiently. The rapid growth in Malaysia's is due to advances in economic development, particularly in the industrial sector such as the rubber and oil palm industries. Thus, as the industrial sector-based economic is growing, a township in Malaysia has started to growth drastically since the early 1970s. In line with the global economic growth and the high labor market in developed countries, had caused population migration to major cities to seize employment opportunities in the industrial sector. According to (Toosi et at., 2012), more than 50 percent of the world's population moves from rural to urban areas. To the extent that economic growth is reflected in urban growth, it is often manifested in changes in land use patterns. In general, some amount of growth can be captured in the existing building stock and associated land use patterns, but increasing growth tends to induce land use change. Therefore, urban development plays a role in providing economic facilities where it can support human life.

In providing facilities for citizens, it requires a large land use spaces since the land usage is increasing from time to time. The changes in land use tend to occur due to urban development to meet the interests of the population. Increasing urban population increases the demand for land for urban activity (Samat, et al., 2011). Thus, the study on land use changes is quite interesting and important because, landscape fragmentation and the impact of such change is a growing need to uphold the natural biodiversity of the region. Geospatial technology used in this study could signify the importance of land cover changes over 
the Pengerang area, which possibly helps to assess the dynamics changes of the area. It also could help to reveals if there is a reduction in natural vegetation cover in the study area.

In this paper, the level of land use change in Mukim Pengerang, Johor Malaysia was examined by using landscape metrics analysis method in FRAGSTAT 4.2, a spatial pattern analysis software. Landscape metrics analysis is used to obtain the applicable changes using the patch analysis. The use of spatial landscape metrics analysis techniques is to examine the percentage of changes of land use type and the shape of spatial changes in understanding the form and stage of land use change within the eight years. This process has led to land-use change or landscape fragmentation. Landscape metrics is an approach to estimate the landscape pattern. Various matrices are available for the examination of the relationship between spatial structures. It is also used in this study to understand patterns of land use change and to give a clear picture of the surrounding change and the comparison within the 2 years.

There are several researches by previous researchers related to landscape pattern/fragmentation. Li et al. (2017) has characterized the landscape patterns in Beijing City, China during 2000 and 2010 using four landscape metrics, i.e. patch density (PD), edge density (ED), Shannon's diversity index (SHDI) and the aggregation index (Al) which two of the metrics used are similar with the research (PD and SHDI). As result, new construction land was found in the original forest land and grassland, leading to a slight increase of PD and SHDI. As overall results, showed that landscape patterns in Beijing City were greatly changed along with the process of urbanization during 2000-2010 and showed obvious spatial differentiation. Similar research using landscape metrics by (Liu et al., 2010) which examine the size, pattern and nature of land use changes. The study demonstrating of landscape metrics which could show the characteristics of the urban expansion in Lianyunggang, China. As result, every expansion of urban development had their different modes and types of land use which can show the different changes of landscape patterns.

A study related to landscape pattern using land use and land cover (LULC) analysis by Jaybhaye et al. (2016) reveals that there was reduction in natural vegetation cover from 1989 to 2015 in Anjaneri Hill, India. The fragmentation analysis for the study area was based on the parameters of class area, percentage of land, number of patches, patch density, total edge length, edge density, and largest patch index. The results obtained from the study revealed an increase in the fragmentation and significant degradation of forests. Similarly, Pang et al. (2010) investigated the changing characteristics of landscape patterns in Zoige County, from 1986 to 2005. Through analysis of LULC driving forces, finally got the conclusions: the climate change and human disturbance factors, including increasing temperature, over-grazing, drainage of water systems, were both responsible for the wetland degradation in Zoige County.

The study of LULC along with fragmentation at the landscape level can help improve understanding of the pace at which conversion of landscape elements is happening and the impacts on ecosystem services as studies of LULC are courser in nature and would not show how each land use is reducing in size, proximity and shape among other things that determine ecosystem services as result on study by Tolessa et al. (2016). The study was conducted to examine composition and configuration of forested landscape in the central highlands of Ethiopia using satellite images of over a period of four decades, and FRAGSTAT raster dataset was used to analyze fragmentation.

Nong et al. (2014) investigated urban growth patterns of the Hanoi capital City of Vietnam from 19932001 which to quantify the speed, growth modes, and resultant changes in landscape pattern of urbanization and examine the diffusion- coalescence and the landscape structural homogenization processes in Hanoi. Through the landscape pattern analysis and comparison with other cities, the result show that the urbanization in Hanoi is limited by its infrastructure systems which make the urban growth not evenly distributed, limiting their competitive advantage disproportionately high transport cost, growing congestion and land market distortions. Kabba \& Li (2011) investigated land use changes, and their ecological effects in Wuhan (1987-2005) by using Remote Sensing techniques extracted land use data, whilst the spatial analyst software, Fragstats quantified ecological metrics at both landscape and class levels. The results showed increased urban and agricultural land uses (1987-2005); with urban land increasing more than 250 percent. Other than that, socioeconomic factors and ecological metrics indeed explained land use changes and their effects in Wuhan.

Other related research by Karami (2014), was carried out in the Zagros vegetative region in the west of Iran to quantify structure and spatial pattern of land uses and forest fragmentation in the Zagros Mountains region. The mosaic analysis method was used for quantifying landscape metrics. The result of 
the study shows that the fragmentation of natural land uses such forest and rangelands should be reducing and maintain large patches of natural vegetation to sustainable land management in this region. Singh et al. (2014) study presents the results of a set of landscape metrics derived from remotely sensed data aiming to characterize the historical trends of landscape changes in the Allahabad district in the period 1990-2010. This study demonstrates the probable use of remote sensing, GIS and FRAGSTAT in assessing spatial structure and change in landscape.

Interest on the study on landscape fragmentation is not only cover on land use changes but also influence on disease emergence. A study by Ferrell \& Brinkerhoff (2018) which to identify patterns and drivers of vector-borne disease risk that may operate at different scales in Virginia. Although the study is not related or similar to this research, but it is quite interesting which the land use or land cover variables could be used for other type of researches. These and other examples show that the landscape fragmentation research attracting more researcher and moving towards interdisciplinary endeavors.

\section{DATA AND METHODS}

\subsection{Study Area}

Mukim Pengerang located in the east of Johor state. There was a rapid development in surrounding areas that become a new growth area in the state of Johor and intended to place as the catalyst for growth in Johor. Among the major developments or mega projects in the region are the development of the gas and oil industry, Refinery and Petroleum Integrated Development (RAPID) and Pengerang Integrated Petroleum Complex (PIPC) (Figure 1). It is about 20,000 acres and the construction started in the year 2012 and growing rapidly which influenced the development of the surrounding area. In the meantime, it encouraged the provision of housing and institutional requirements for the residents. Therefore, there is an extension of land use for land development and land use change as a result of the major developments. Total populations in this mukim are 125,544 people (year 2010) and the population density is 82.53 people per $\mathrm{km}^{2}$. With the economic development and increasing of population, the surrounding land use in Mukim Pengerang has changed between 2008 and 2017.
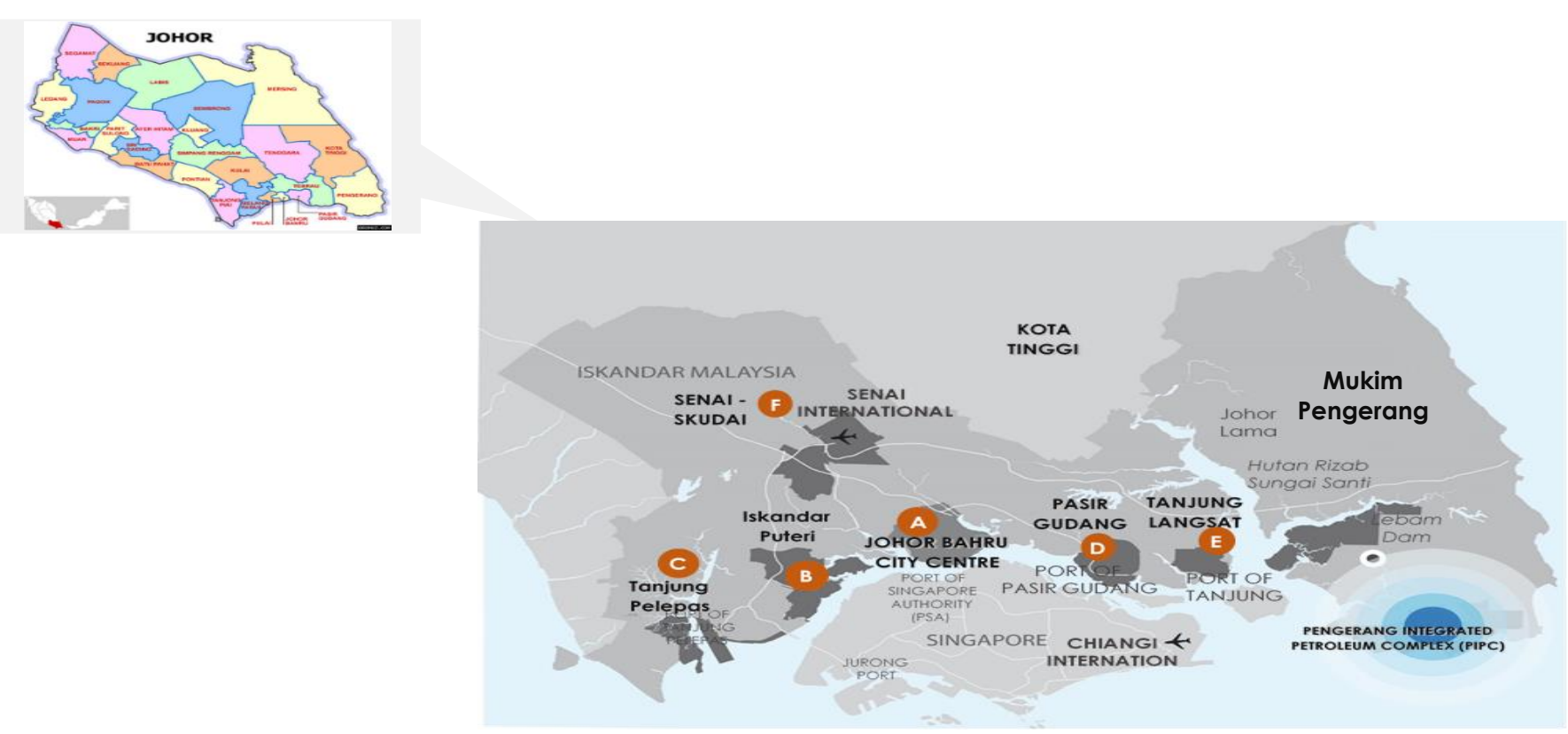

Figure 1. Industrial Project of PIPC effect the surrounding of Mukim Pengerang 


\subsection{Methods}

In monitoring spatial pattern changes, land use data was prepared using ESRI ArcGIS 10 software to oversee the classification of land use classes. Geographical Information Systems (GIS) approaches have added a new dimension to the understanding of these changes, not least the urban landscape (Wu, 2008; Wu et al., 2006; Yuan et al.,2005). GIS could offer the platform on which data on such images are stored, processed and analyzed for decision making. The land use data collected and prepared for this study was in shapefile format and classified by classes. There are several land uses classes that used in this study as shown in Table 1. Based on the land use data (Figure 2), the dominant land use classes in this area for both years are agriculture which is about 223,292.90 acres (year 2008) and 220,078.35 acres (year 2017). While, for other land use classes which is built-up area 12,648.99 acres (year 2008), 21,709.25 acres (year 2017) and forest 28,829.41 acres (year 2008), 28,016.05 acre (year 2017). As shown in this data, the acreage of agriculture becomes decreased as the built-up area becomes expanded in 2017. Thus, (Table 1) shows the agriculture land use class has converted into a built-up area for development in this area.

Table 1. Land Use Classification

\begin{tabular}{cc}
$\begin{array}{c}\text { Land Use Classes } \\
\text { Agriculture }\end{array}$ & $\begin{array}{c}\text { Description } \\
\text { Almost all are green gardens, small size corn and fruit gardens that are generally located in } \\
\text { gardens. }\end{array}$ \\
\hline Forest & Mixed of plants with a higher density of trees and plants. \\
\hline Built-up & Residential, commercial, industrial, transportation and facilities. \\
\hline
\end{tabular}
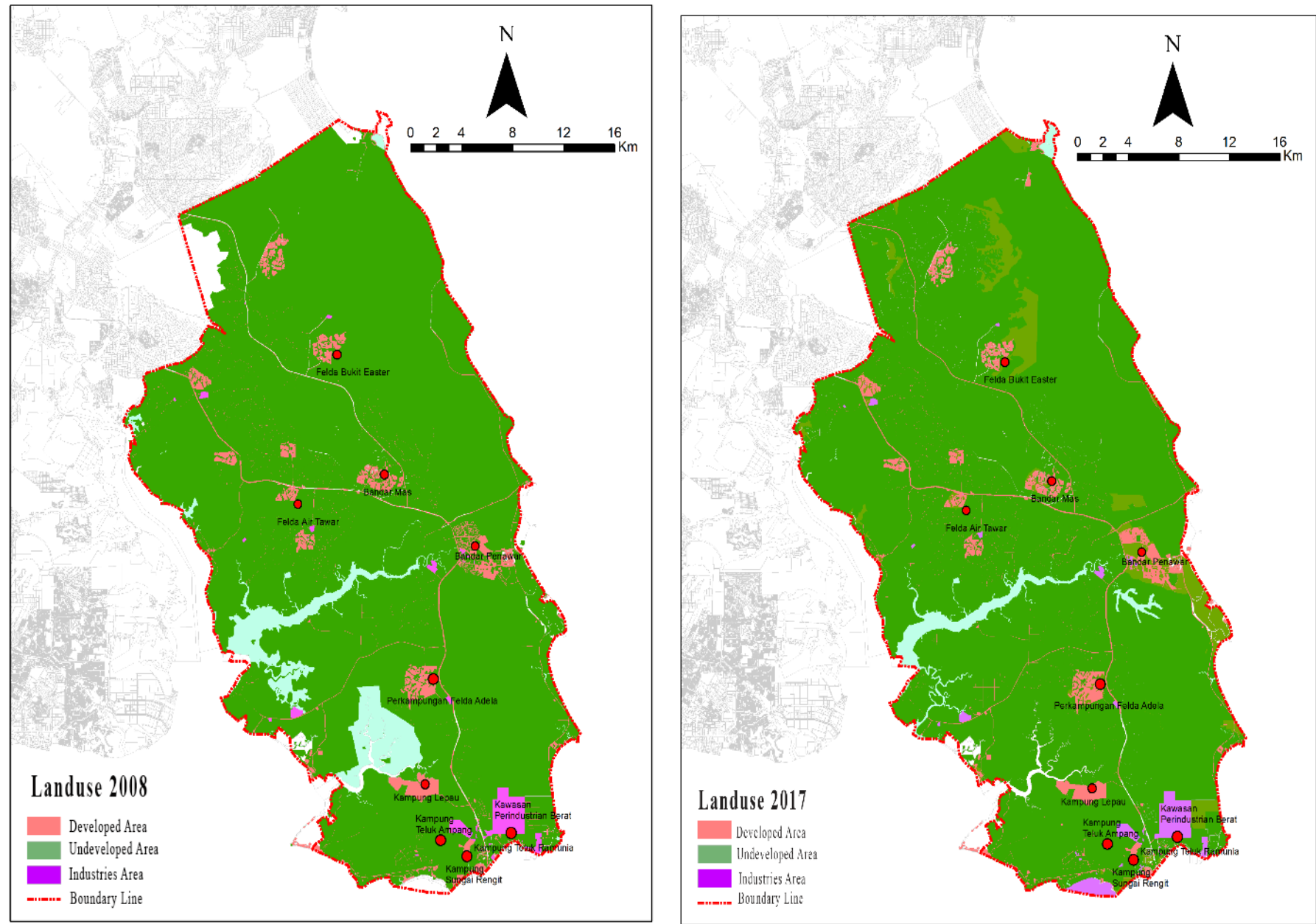

Figure 2. Raster Image of Mukim Pengerang, 2008 and 2017 
To obtain the applicable changes using matrix statistical analysis, patch analysis was used. The used of spatial metrics analysis techniques is to examine the percentage of changes in the type of land use and the shape of spatial change (Figure 2). This spatial change study can be applied using GIS to make the results more efficient. This is because by using GIS, spatial metrics changes not only be produced in the category of classes but also by the diversity of area which either homogeneous or heterogeneous. Classification technique is too accurate in ensuring precise change-detention results. Furthermore, the data collected in two differences years (2008 and 2017) give a comparison of the fragmentation result between both years.

Spatial pattern analysis software FRAGSTATS 4.2 is applied to calculate landscape metrics of each class type and total landscape after it was converted into raster image from shapefile format. FRAGSTAT 4.2 provides a very comprehensive set of spatial statistics and descriptive metrics of the pattern at the patch, class, and landscape levels (Haines-Young \& Chopping, 1996). In analyzing the fragmentation of landscape in the study area and correlated the changes throughout the years, quantify landscape metrics was used at both landscape and class levels. There are several class-level metrics as shown in Table 2.

Table 2. Class-Level Metrics

$\begin{aligned} & \text { Index (Unit) } \\ & \text { (\#) } \\ & \text { (Number of Patches) }\end{aligned}$
$\begin{aligned} & \text { Where: } \\ & \mathrm{n}_{\mathrm{i}}=\text { number of patches of the corresponding } \\ & \text { land use class }\end{aligned}$
\[ \begin{array}{l}\text { PD (Patch Density) } \\ \text { Higher NumP indicates greater fragmentation. }\end{array} \]

Where:

$\mathrm{ni}=$ number of patches of class

$A=$ total of the class area $\left(\mathrm{m}^{2}\right)$

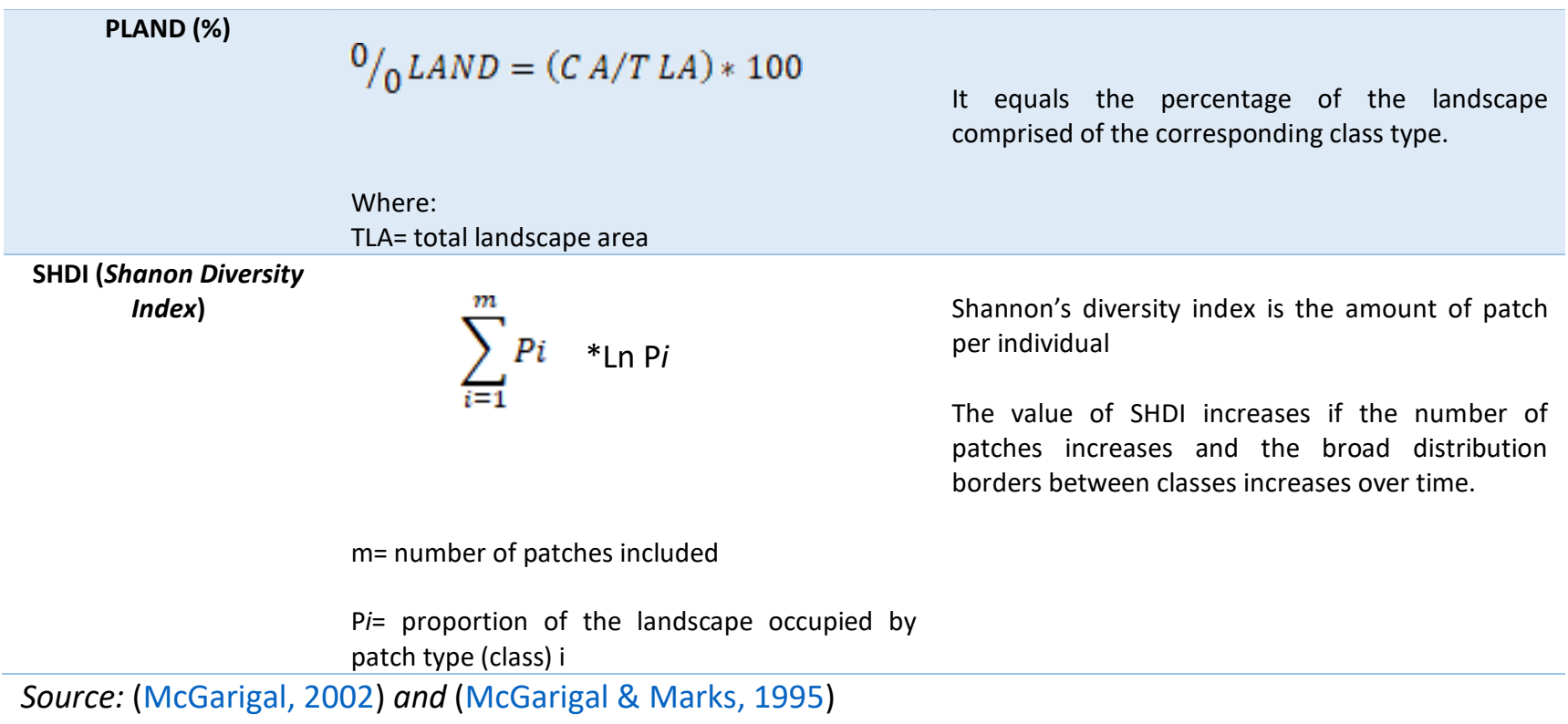




\section{RESULTS AND DISCUSSION}

\subsection{Fragmentation Analysis}

In 2008 and 2017, the most changing classes (agriculture, forest, and built-up area) are chosen to compute spatial landscape at class level by means of FRAGSTAT software. Based on the result (Table 3 ), in Mukim Pengerang, agriculture is represented as a dominant class of landscape because it has a larger percentage of total area. Meanwhile, the statistic of agriculture showed that the percentage of landscape (PLAND) index decreased from 81.38 to 78.6, while the number of patches (NP) increased from 228 to 427 during the whole period from 2008 to 2017. This combination result shows that there are breaking up of the agriculture areas into small areas. Besides, Patch Density (PD) result shows non-isolated in certain areas that caused break up patches. This shows that agriculture land use becomes decrease because of development expanded to the surrounding of the study area throughout the years.

Table 3. Class-Level Metrics of 2008 and 2017

\begin{tabular}{|c|c|c|c|c|c|c|c|c|}
\hline Land Use & $\begin{array}{c}\text { Class Area } \\
\text { (CA) } \\
2008\end{array}$ & $\begin{array}{c}\text { Class Area } \\
\text { (CA) } \\
2017\end{array}$ & $\begin{array}{c}\text { NP (\#) } \\
2008\end{array}$ & $\begin{array}{l}\text { NP (\#) } \\
2017\end{array}$ & $\begin{array}{c}\text { PD } \\
2008\end{array}$ & $\begin{array}{c}\text { PD } \\
2017\end{array}$ & $\begin{array}{l}\text { PLAND } \\
\text { (\%) } 2008\end{array}$ & $\begin{array}{l}\text { PLAND } \\
\text { (\%) } 2017\end{array}$ \\
\hline Agriculture & $94,690.34$ & $93,792.79$ & 228 & 427 & 0.37 & 0.19 & 81.378 & 78.6 \\
\hline Forest & $11,305.26$ & $11,124.26$ & 141 & 1,025 & 0.88 & 0.12 & 9.716 & 9.57 \\
\hline Buit-up & $3,874.74$ & $4,689.51$ & 8,322 & 6,948 & 1.18 & 5.82 & 3.33 & 3.93 \\
\hline
\end{tabular}

In regards to forest area during period 2008-2017, the number of patches (NP) increased from 141 to 1025. Similarly, the percentage of the landscape (PLAND) index decreased from 9.72 to 9.57 . Thus, it shows that forest land use becomes decreased and breaking up into smaller patch caused by the development of the surrounding area. While the value of the built-up area metrics shows a change in the increasing percentage of landscape index (PLAND) from 3.33 to 3.93. These show that urban development in the study area has taken place. Meanwhile, the number of patches (NP) has also decreased from 8,322 to 6,948 . However, the PD value for built-up is increasing. This shows that urban change is increasing by 2017 and the shape of the development density is a group based on patch saturation value is increasing in 2017.

Table 4. Metrics of landscape structure for selected indices at the landscape level, 2008 and 2017

\begin{tabular}{cccc}
9 & NP (\#) & PD & SHDI \\
\hline $\mathbf{2 0 0 8}$ & 10,089 & 8.67 & 0.696 \\
$\mathbf{2 0 1 7}$ & 8,187 & 6.86 & 0.818 \\
\hline
\end{tabular}

For SHDI, based on the value for 2008 and 2017, it shows an increasing value (Table 4). This situation illustrates that the higher the SHDI value for land use, the higher the level of land use compositions. This is because the growing pattern of land use is reflected by a large number of patches due to the diversification of land use activities within a given area. Based on this study results, it shows an agreement with the findings of Singh et al. (2014) and Tolessa et al. (2016). These study and some previous study results related to land use changes therefore proved the capability of remote sensing and GIS to quantify changes in natural resource over time.

\section{CONCLUSION}

In conclusion, based on the result, land use change in Mukim Pengerang is more frequent in 2008 compared to 2017. This resulted in the use of agricultural land and forests in 2017 due to urban development caused by the development of the petroleum industry project. Overall, from the metrics statistics, it was found that there was a significant change in land use over a period of 8 years. This study is an analysis that aims to know and understand the land use structure against the effects of ecology. This study was also conducted to determine the level of land use change. This is because measuring land use change or landscape is very important for understanding the structure of land use against relevant ecological effects. 


\section{REFERENCES}

Ferrell, A., \& Brinkerhoff, R. (2018). Using Landscape Analysis to Test Hypotheses about Drivers of Tick Abundance and Infection Prevalence with Borrelia burgdorferi. International Journal of Environmental Research and Public Health, 15(4), 737. [Crossref]

Haines-Young, R., \& Chopping, M. (1996). Quantifying landscape structure: a review of landscape indices and their application to forested landscapes. Progress in Physical Geography: Earth and Environment, 20(4), 418-445. [Crossref]

Jaybhaye, G. R., Kale, K. P., \& Joshi, P. (2016). The Relevance of Geospatial Techniques in the Assessment of Forest Fragmentation of Anjaneri Hill, Nasik District, Maharashtra, India. J Environ Sci Toxicol Food Technol, 10(4). [Crossref]

Kabba, V. T. S., \& Li, J. (2011). Analysis of Land Use and Land Cover Changes, and Their Ecological Implications in Wuhan, China. Journal of Geography and Geology, 3(1). [Crossref]

Karami, A. (2014). Structure and spatial pattern of land uses patches in the Zagros Mountains region in the west of Iran. Biodiversitas, Journal of Biological Diversity, 15(1), 53-59. [Crossref]

Li, H., Peng, J., Yanxu, L., \& Yi'na, H. (2017). Urbanization impact on landscape patterns in Beijing City, China: A spatial heterogeneity perspective. Ecological Indicators, 82, 50-60. [Crossref]

Liu, X., Li, X., Chen, Y., Tan, Z., Li, S., \& Ai, B. (2010). A new landscape index for quantifying urban expansion using multi-temporal remotely sensed data. Landscape Ecology, 25(5), 671-682. [Crossref]

McGarigal, K. (2002). FRAGSTATS: Spatial Pattern Analysis Program for Categorical Maps. Computer software program produced by the authors at the University of Massachusetts, Amherst. Http://Www. Umass. Edu/Landeco/Research/Fragstats/Fragstats. Html.

McGarigal, K., \& Marks, B. J. (1995). FRAGSTATS: spatial pattern analysis program for quantifying landscape structure. U.S. Department of Agriculture, Forest Service, Pacific Northwest Research Station. [Crossref]

Nong, D., Lepczyk, C., Miura, T., Fox, J., Spencer, J., \& Chen, Q. (2014). Quantify spatiotemporal patterns of urban growth in Hanoi using time series spatial metrics and urbanization gradient approach. [Crossref]

Pang, A., Li, C., Wang, X., \& Hu, J. (2010). Land Use/Cover Change in Response to Driving Forces of Zoige County, China. Procedia Environmental Sciences, 2, 1074-1082. [Crossref]

Samat, N., Ghazali, S., Hasni, R., Hadary, Y. A. El, \& Fatimah. (2011). Land Use Changes and Its Impact on Local Communities in Seberang Perai, Pulau Pinang. In Seminar Kebangsaan Masyarakat, Ruang dan Alam Sekitar.

Singh, S. K., Pandey, A. C., \& Singh, D. (2014). Land Use Fragmentation Analysis Using Remote Sensing and Fragstats. In Society of Earth Scientists Series (pp. 151-176). Springer International Publishing. [Crossref]

Tolessa, T., Senbeta, F., \& Kidane, M. (2016). Landscape composition and configuration in the central highlands of Ethiopia. Ecology and Evolution, 6(20), 7409-7421. [Crossref]

Toosi, N. B., Fakheran, S., \& Soffianian, A. (2012). Analysis of Landscape Pattern Changes in Isfahan City During The Last Two Decades, International Conference on Applied Life Sciences, pg. 1012. In International Conference on Applied Life Science.

Wu, J. (2008). Making the Case for Landscape Ecology: An Effective Approach to Urban Sustainability. Landscape Journal, 27(1), 41-50. [Crossref]

Wu, Q., Li, H., Wang, R., Paulussen, J., He, Y., Wang, M., ... Wang, Z. (2006). Monitoring and predicting land use change in Beijing using remote sensing and $\{\mathrm{GIS}\}$. Landscape and Urban Planning, 78(4), 322-333. [Crossref]

Yuan, F., Sawaya, K. E., Loeffelholz, B. C., \& Bauer, M. E. (2005). Land cover classification and change analysis of the Twin Cities (Minnesota) Metropolitan Area by multitemporal Landsat 
Che'Man \& Salihin/ Geoplanning: Journal of Geomatics and Planning, Vol 5, No 2, 2018, 229-236 doi: 10.14710/geoplanning.5.2.229-236

remote sensing. Remote Sensing of Environment, 98(2-3), 317-328. [Crossref] 